\title{
EFFICIENCY OF FOOD INDUSTRY FUNCTIONING OF UKRAINE: ANALYSIS AND DIRECTION OF COMPETITIVENESS SECURITY
}

\author{
NATALIIA KUPRINA
}

\begin{abstract}
The food industry in each country is a strategic industry that ensures its food security, environmentally friendly social aspects, safe products, health of the population and its economic security, as it is continuously operating even at times of economic and political crises. Therefore, the state of the industry and the efficiency of its operation require constant analysis and research.

This publication analyses the performance of the food industry of Ukraine and in particular its very important region for its development and export advantages - Odessa. The paper considers also the aspects of effective development and competitiveness of the food industry in Ukraine.
\end{abstract}

Keywords: national economy, food industry, restructuring, efficiency of operation, competitiveness, adaptation, transformation of activity.

JEL codes: D24, M13, M21, O12, R10.

\section{Introduction}

The state and development of the national economy and its entities depends on the factors of the internal and external environment, the latter often being the dominant ones. A stable economic system of the country is not possible without effective functioning of enterprises - the entities of the national economy and the protection of domestic producers. This is especially important for such an industry as the food industry, which provides not only economic, but also food security and the social component of any country, which confirms its strategic importance. 
Therefore, an important aspect is to ensure effective functioning of the food industry, as well as its competitiveness and the direction of development. All of the above mentioned requires the analysis of its state and performance, as well as the publication of scientists on this issue.

The questions of the research into the transformation of the activity of economic systems and entities of the national economy, as well as adaptation to changes in the external environment, were dealt with by many scientists, for instance:

- transformational processes: Aistova M., Bardish G., Burkinsky B., Galyuka I., Gavrilishina B., Heiets V., Grazhevskaya N., Budkina V., Vergunenko N., Zhilyaeva I., Kapitanets Y., Klimchuk S., Kovalova A., Limonova E., Litvina O., Mandibles V., Martsin V., Marchuka L., Mocherny S., Petrishina N., Pastukhova E., Turilo A., Chaloy O., Chizhenkova E., Hammer M., Chamspi J., etc.;

- adaptation and adjustment processes: Alekseev S., Budnik M., Burkinsky B., Dubchak V., Heiets V., Kapitanets Y., Krysko Zh., Kulikov P. Kozachenko A., Lyashenko A., Minko I., Pokotilo S., Padalko G., Ponomarev V., Rastrygin L., Sukhoverha Y., Chizhenkova E., Shamina K., Yachmenova V., Acoff Russell F., Magiston J., Eddison Herbert J., etc.;

- restructuring of the subjects of the national economy, as a process to ensure the efficiency of operation and competitiveness: Alimova O., Amoshi O., Stork M., Antonyuk P., Bilyk M., Burkinsky B., Butenko A., Vodachek L., Vandenbort M., Heiets V., Deineko L., Evseeva A., Karpinskaya A., Klimchuk S., Kovaleva A., Kotlubay A., Korotkova T., Klisheiko A., Krisanova D., Kordana K., Lukinova I., Minakova S., Oganezova A., Sklyar E., Slyusar V., Tereshchenko O., Trillenberg V., Chekalovets V., Chumachenko N., Shvygova K., Shapiro V., Folmen T., etc.

However, in the modern conditions there are additional issues confirming the purpose of the study:

- the state of the food industry in Ukraine, which requires analysis and research;

- the direction of development and ensuring the competitiveness of this sector of the national economy, which is of such importance and strategic significance.

The hypothesis put forward in this study is as follows: the food industry of Ukraine, as a strategic branch of industry, requires transformation in the modern conditions to adapt to profound changes in the external environment.

\section{Methodology, data sources}

The theoretical and methodological basis of the study is the publications of foreign and Ukrainian scientists on this issue, information materials from the websites of vertically integrated business associations in Ukraine, statistics from the main statistics department of Odessa region for 2015-2017 to analyze efficiency of the functioning of the food industry in Odessa region, namely: net profit, profitability of operating activities, production of certain types of products, number of enterprises, share of unprofitable enterprises.

To solve the research problems and the proposed hypothesis of the research, the following methods were used: the method of structurally logical analysis to form 
the structure and logic of this publication, analytical and comparative analysis to study the essence of the concepts of "adaptation", "enterprise adaptation", "adaptation of the economic system", "persistence of activity"; the method of absolute and relative values, the method of comparative economic and statistical analysis for analyzing the performance of food industry enterprises functioning in Odessa region and the most profitable vertically integrated structures of the food industry and agro-industrial sector in Ukraine and Europe; a graphical method for determining the dependence of the categories "efficiency", "competitiveness", "persistence of activity" of entities of the national economy.

\section{Analysis of the performance of the food industry functioning in Odessa region}

Odessa is one of the important regions of Ukraine, where the food industry is widely represented, due to good climatic conditions and geographical location (presence of three ports for export-import operations), a sufficient number of labour and financial resources. The conducted study was based on the example of Odessa region. The analysis of production and financial results should be carried out on the basis of the statistical data presented in Tables 1-4 (Holovne upravlinnia..., 2018, pp. 1-46).

The studies show that the dynamics of production of products by the enterprises of the food industry of Odessa region for the period 2015-2017 is not positive generally. Thus, the increase in production is observed in such export types as vegetable oil and certain types of wine, as well as in some types of vegetables, juices, mineral and sweet water. The analysis of the financial results obtained in 2017 showed that many sub-sectors of the food industry in Odessa region were unprofitable (Table 2), which is negative phenomenon and is confirmed by the data on the profitability of products (Table 3 ), which is rather low.

Table 1

Production of certain types of food prodacts and beverages in Odessa region (fragment)

\begin{tabular}{lccc}
\hline \multicolumn{1}{c}{ Types of products } & $\mathbf{2 0 1 5}$ & $\mathbf{2 0 1 6}$ & $\mathbf{2 0 1 7}$ \\
\hline Beef and veal, t & 106 & 73 & 61 \\
Fresh or chilled pork, t & 580 & 601 & 527 \\
Mutton, t & 63 & 48 & 41 \\
Food offal of cattle, pigs, sheep, goats, horses, other equines, t & 87 & 21 & 34 \\
Hens, chickens (carcasses), t & 16 & 7 & 5 \\
$\begin{array}{l}\text { Pork (including bacon, 3/4 of the pork side, loin pieces and cuts } \\
\text { thereof) salted, split, dried or smoked, tons }\end{array}$ & 468 & 362 & 341 \\
$\begin{array}{l}\text { Salted beef and veal, in brine, dried or smoked, tons } \\
\text { Salted meat, in brine, dried or smoked; fine meal and meal from meat } \\
\text { or meat by-products, tons }\end{array}$ & 56 & $\ldots{ }^{*}$ & $\ldots{ }^{*}$ \\
$\begin{array}{l}\text { Sausage products and similar products from meat, offal or animal blood } \\
\text { and similar products and food products based on them, tons }\end{array}$ & 5,502 & 242 & 182 \\
$\begin{array}{l}\text { Tomato juice, thousand l } \\
\text { Apple juice, thousand 1 }\end{array}$ & $14,396.7$ & $16,384.4$ & $16,741.2$ \\
\hline
\end{tabular}


cont. Table 1

Mixture of fruit and vegetable juices, thousand 1

The juice of a single fruit or vegetable, unfermented and without the addition of alcohol (except for orange, grapefruit, pineapple, tomato, grape and apple juice) non-concentrated, 1

Canned peas without addition of vinegar or acetic acid

(except for ready vegetable dishes), $\mathrm{t}$

Tomato puree and pasta, Concentrated, $\mathrm{t}$

Vegetables (except potatoes), fruit, nuts, mushrooms and other edible parts of plants, prepared or preserved with vinegar or acetic acid, $t$

Jam, marmalade, mashed potatoes, jellies, marmalades, jam, preserves, from other fruit and nuts, cooked (except for products homogenized), $t$

Unrefined sunflower oil and its fractions (except chemically modified), $\mathrm{t}$

Non-condensed milk and cream and without adding confititure or other sweeteners with a fat content of more than $1 \%$, but not more than $6 \%$, in primary packages with a net volume of not more than 2 litres, $t$

Butter with fat content of not more than $85 \%, t$

Fresh unfermented cheese, $\mathrm{t}$

Grated, powdered, blue and other non-melted cheese, $\mathrm{t}$

Coagulated milk and cream, yogurt, kefir, sour cream

and other fermented products, tons

Liquid yogurt and fermented milk flavoured, $\mathrm{t}$

Rice (bleached) semi-refined or fully refined, polished or not, glazed or not, $\mathrm{t}$

Wheat flour or wheat-rye flour, $t$

Grain and wholemeal flour from soft wheat, $t$

Cereals, wholemeal flour from oats, corn, rice, rye, barley

and other cereals (except wheat), $t$

Cereal grains rolled, processed into flakes, peeled, split, cut or crushed, $t$

Bread and bakery products, short-term storage, $t$

Cakes and pastry; other food products with addition of sweeteners, $t$

Sweet biscuits, $\mathrm{t}$

Uncooked pasta (except for products containing eggs, stuffed

or cooked in another way), $t$

Sparkling wine from fresh grapes (except wine), thous. dal

Sparkling wine "Champagne of Ukraine", thous. dal

Wine with an actual alcohol concentration of not more than $15 \%$

(except for fizzy, sparkling, and wine with a protected designation

of origin), thous. dal

Wine with an alcohol concentration of more than $15 \%$

(Port, Madera, Sherry and others), thous. dal

Non-carbonated natural mineral waters, thous. dal

Natural mineral fizzy waters, thous. dal

Waters with added sugar and substances sweetened or flavouring others,

i.e. soft drinks such as lemonade, orangeade

(excluding mineral and carbonated), thous. dal

" Data is not published in order to ensure compliance with the requirements of the Law of Ukraine „On State Statistics" of confidentiality of statistical information.

Source: Holovne upravlinnia statystyky v Odeskii oblasti (2018).

\begin{tabular}{|c|c|c|}
\hline $41,799.5$ & $53,436.5$ & $60,680.9$ \\
\hline $24,800.3$ & $18,563.3$ & $19,824.0$ \\
\hline 3,536 & 1,842 & 2,020 \\
\hline 6,248 & 4,265 & 5,290 \\
\hline 2,158 & 2,493 & 2,956 \\
\hline$\ldots{ }^{*}$ & 1,626 & 1,588 \\
\hline 529,176 & 754,524 & $1,014,534$ \\
\hline 4,450 & 5,221 & 4,977 \\
\hline 920 & 1,233 & 1,202 \\
\hline 722 & 620 & 621 \\
\hline 555 & 905 & 1,171 \\
\hline 3,403 & 3,771 & 3,703 \\
\hline 553 & 512 & 654 \\
\hline$\ldots{ }^{*}$ & 15,417 & 17,427 \\
\hline 106,776 & 108,936 & 107,587 \\
\hline 1,404 & 1,264 & 405 \\
\hline 1,075 & - & $\ldots{ }^{*}$ \\
\hline- & 1,003 & 1,239 \\
\hline 80,791 & 77,997 & 71,648 \\
\hline 7,798 & 7,404 & 6,416 \\
\hline 1,233 & 759 & 540 \\
\hline 591 & $\ldots^{*}$ & $\ldots{ }^{*}$ \\
\hline $2,656.3$ & $2,717.0$ & $2,287.7$ \\
\hline $2,121.1$ & $1,899.3$ & $1,365.7$ \\
\hline $3,250.2$ & $2,735.7$ & $3,441.6$ \\
\hline 732.9 & 824.1 & 467.7 \\
\hline 805.3 & 1347.5 & $1,045.7$ \\
\hline 948.1 & 708.0 & $1,004.9$ \\
\hline 173.6 & 579.9 & 2506.5 \\
\hline
\end{tabular}


Net profit (loss) in 2017 in Odessa region (mln. UAH)

\begin{tabular}{lc}
\hline \multicolumn{1}{c}{ Types of products } & $\mathbf{2 0 1 7}$ \\
\hline Production of food, beverages and tobacco products & 679.8 \\
Food production & 612.2 \\
meat and meat products production & -31.8 \\
processing and canning of fish, crustaceans and molluscs & $\ldots{ }^{*}$ \\
processing and canning of vegetables and fruit & 68.1 \\
oil and animal fat production & 630.6 \\
dairy production & 7.2 \\
production of flour-and-cereals products, starch and starch products & -25.9 \\
production of bread, bakery and flour products & 19.2 \\
food production & -46.8 \\
Beverage industry & 67.6 \\
including & \\
distillation, rectification and mixing of alcoholic beverages & $\ldots{ }^{*}$ \\
wine production & 68.2 \\
production of soft drinks; production of mineral waters and other bottled waters & 0.0 \\
\hline
\end{tabular}

* Data is not published in order to ensure compliance with the requirements of the Law of Ukraine „On State Statistics" of confidentiality of statistical information.

Source: Holovne upravlinnia statystyky v Odeskii oblasti (2018).

Table 3

Profitability of operating activities in 2017 in Odessa region (\%)

\begin{tabular}{lc}
\hline \multicolumn{1}{c}{ Types of products } & $\mathbf{2 0 1 7}$ \\
\hline Production of food products, beverages and tobacco products & 4.3 \\
Food production & 4.4 \\
meat and meat products production & 0.8 \\
processing and canning of fish, crustaceans and molluscs & $\ldots{ }^{*}$ \\
processing and canning of vegetables and fruits & 9.1 \\
oil and animal fat production & 5.4 \\
dairy production & 1.6 \\
production of flour-and-cereal products, starch and starch products & -1.7 \\
production of bread, bakery and flour products & 2.1 \\
food production & -4.1 \\
Beverage industry & 4.3 \\
including & \\
distillation, rectification and mixing of alcoholic beverages & $\ldots{ }^{*}$ \\
wine production & 4.1 \\
production of soft drinks; production of mineral waters and other bottled waters & 0.8 \\
\hline
\end{tabular}

* Data is not published in order to ensure compliance with the requirements of the Law of Ukraine „On State Statistics" of confidentiality of statistical information.

Source: Holovne upravlinnia statystyky v Odeskii oblasti (2018). 
The state of this industry is also confirmed by the financial stability of enterprises, where receivables and payables amount to UAH 8,097.4 million and UAH 10,345 million, respectively (Holovne upravlinni..., 2018, p. 4).

Table 4 shows the analysis of presence of food industry enterprises and their profitability. From the table it follows that there is an increase in food industry enterprises, including the increase due to the growth of small businesses, which is a positive trend. However, in some sub-sectors of the food industry the level of unprofitable enterprises, as the study showed, reaches 38-40\% (Holovne upravlinni..., 2018, pp. 3-5).

Table 4

Number of enterprises by types of food industry in Odessa region

\begin{tabular}{lccc}
\hline \multirow{2}{*}{ Food production } & & Year & \\
\cline { 2 - 4 } & 2015 & 2016 & 2017 \\
\hline Food production, & 355 & 325 & 367 \\
beverages and tobacco & & & 311 \\
- of which small enterprises, & 299 & 268 & 224 \\
including: microenterprises & 220 & 189 & \\
\hline
\end{tabular}

Source: Holovne upravlinnia... (2018).

The analysis of the state of the food industry in such a large and progressive region, as Odessa region, showed that there is a need to find ways to adapt to new conditions of functioning and overcoming crisis processes in the economy.

\section{Directions of transformational changes in the food industry in Ukraine}

The research on the approaches of scientists to the definition of the conceptual and categorical apparatus of the concepts "adaptation", "adaptation of an enterprise", "adaptation of the national economy" showed the existence of the ambiguity of their definition:

- the adaptation of enterprises is the process of adapting their parameters to uncertain environmental conditions, which ensures an increase in the efficiency of their functioning during the entire life cycle (Chizhenkova, 2005);

- the adaptation of an enterprise as an economic system is a process of forced adaptation of the enterprise to changes in living conditions, and changes that can occur both in the external environment (at the macro and micro levels) and in the internal environment of the enterprise (Minko and Shamina, 2011);

- the enterprise adaptation is the process of adapting to environmental variability; it is a process that accompanies its entire life cycle, and adaptation measures must be focused and strategic in nature, which means that they should be considered as elements of strategic enterprise management (Kulikov, 2010);

- the adaptation of an economic system is the process of adapting the economic system, its subsystems and individual elements to the changing conditions of the external or internal environment in order to ensure the survival of the system, stability and to establish a dynamic balance between the system and the environment (Ackoff, Magidson and Addison, 2007); 
- the enterprise adaptation is the process of purposeful change of the parameters, structure and properties of any entity in response to changes occurring both in the external environment of the entity's activity and inside it (Kozachenko, Ponomarev and Lyashenko, 2003);

- the adaptation is the process of developing and implementing measures aimed at changing the internal environment of the enterprise in accordance with the requirements of the external environment (Alekseev, 2000) etc.

As the study of Kapitanets (2007) shows, the mechanism of adaptation of the entity to the external environment will be based on the principle of adaptability, according to which an enterprise is considered an adaptive system that can function effectively in unforeseen changes of its goals and characteristics or the environment by changing the algorithm of functioning or searching for the optimal state. According to this scientist, adaptability - i.e. the constant adaptation of the system - is achieved through feedback information and an immediate adequate response to changes that occur under the influence of external factors. Kapitanets defines the adaptation as a complex process that begins with complex diagnostics and can end with the reorganization of the structure and becomes for many enterprises not only the way out of financial crisis conditions, but also the way to ensure economic security by increasing the efficiency of resource use, maintaining market positions.

As it was shown by the previous research (Kuprina, 2013), the adaptation to the external environment is a milder process than transformation or reorganization and, in this context, it is necessary to take into account not the principle of adaptability, but the principle of imparity, as a way of responding to an profound change in the external environment. The principle of "imparity" (inequality), as a manifestation of the principle of caution, is considered in the publications of foreign scientists and practitioners in various sectors of the economy, but has not been studied enough by Ukrainian scientists. Thus, in Ukraine, in this aspect the principle of imparity of enterprises activity is used, for example, when creating a reserve of doubtful debts for receivables, performing devaluation procedures for stocks and fixed assets, but using it is rather intuitive, not supported by methodological and regulatory framework, without clear definition and justification for its use (Kuprina, 2011a).

The study made it possible to substantiate the need for transformation of the food industry activity on the basis of the principle of imparity with the emphasis on the category of "persistence of activity" reflecting the degree of its stability (Fig. 1). Thus, such an approach to assessing the activity of an enterprise and the rejection of the concept of "sustainability", "stability" is largely associated with the widespread use of these terms in various areas of economic science at the level of the research on the functioning of an enterprise: financial sustainability, strategic sustainability, and technological sustainability, stability of the activity, stability of the development, etc., and allows us to select the intersection of the categories of "effectiveness" of the activities of the entity of the national economy and its "competitiveness" (Kuprina, 2013). 


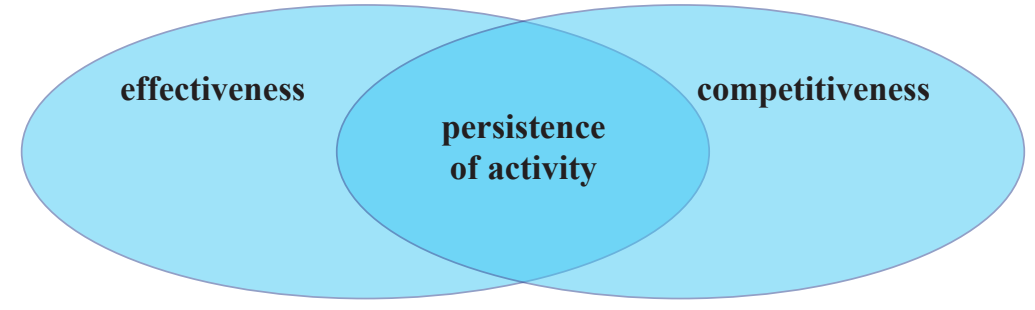

Fig. 1. The relationship between the categories of "effectiveness" and "competitiveness" of the entity of the national economy.

Source: compiled by the author.

As it was shown by the previous research (Kuprina, 2013), it is necessary to take into account the desire and ability of the economic system, namely the enterprise, not only to maintain an equilibrium characterizing sustainability, stability but, at the same time, to have the ability to develop, and not to stay conservative. Therefore, such terms as "permanence" (in French permanent, from Latin permaneo - remain, continue), continuously ongoing, permanent, "fixity" (from English fixity - immobility, stability), "homeostasis" (the desire and ability of the economic system to maintain an equilibrium state, which characterizes the sustainability, stability, and at the same time, maintains the conservatism of the system). Persistence (from Lat. Persisto - I remain, I persist) is the property of something to maintain a constant (stable) state, not precluding sustainable development and functioning, is subject to wide variation (Znachenie terminov..., 2019). This term has not been used in economics, but is mainly used in the field of ecology, biology, mathematics and programming. As it has been justified (Kuprina, 2013), in our opinion, to analyze the persistence of activities, it is necessary to evaluate the economic efficiency based on the proposed methodological approach to analyzing the performance of the enterprise and the methodical approach to analyzing the competitiveness of the activity based on the theory of effective competition, which is the most accessible and less cumbersome and graphically designed for use in the practical activity of the enterprise.

According to A. Porter, the content of the concept of "competition" significantly affects the globalization process, which highlights the concept of "competitive advantage" instead of comparative, which allows the company not only to work productively, but also to constantly improve ways of competition and to increase productivity, through the use of innovations not only in production, but also in marketing activities and in the provision of services. The author notes that countries (or regions) create the environment that either promotes or does not contribute to the competitiveness of companies, therefore, companies are competing, not countries (or regions) (Porter, 2005). Therefore, it is business entities - enterprises in a market economy - which seek to find ways and methods to ensure efficient operation and competitiveness with the state support of a domestic producer. The study made it possible to assert that transformation, as one of the structural components of the restructuring of 
an industrial enterprise, is a transformation of its activity through the implementation of a system of measures (organizational, legal, financial, economic and productiontechnical), allowing to ensure and improve the competitiveness and efficiency of the entrepreneurial entity in accordance with changes in the external environment and the strategy of its development. The direction of preserving the competitiveness and efficiency of the national producer in accordance with significant changes in the external environment is the formation of vertically integrated structures - holdings (rigid transformation of activities), cluster formations and associations (moderate transformation of activities), implementation of activities based on other outsourcing approaches (mild activity transformation) (Kuprina, 2012).

The research work of domestic scientists showed that (Kuprina, 2011b) the least studied sector for the formation of cluster structures is the food industry and the processing of agricultural products, and the food market is one of the vital ones and will exist even during economic and financial crises. In addition, there is an increased competition between food producers in the domestic market. It is necessary to find ways to protect such domestic producers. In the European countries with market economies, clusters cover many areas of the food industry and agribusiness (Table 5), as the study showed (Kuprina, 2011b), and in Ukraine, which has a huge potential in the field of production, both agricultural products and their processing, are represented by only a few companies, whereas only in Italy there are 21 clusters operating in this field.

Table 5

The scope of the cluster structures of the food industry and agriculture of some countries of the world

\begin{tabular}{lccccc}
\hline \multirow{2}{*}{ A country } & \multicolumn{5}{c}{ Scope of activity } \\
\cline { 2 - 5 } & Food & Meat-food & Winemaking & AIC & Technology AIC \\
\hline 1. Austria & & & & & + \\
2. Denmark & + & + & & + & + \\
3. Italy & + & + & & & + \\
4. Finland & + & & + & + & + \\
5. France & & + & & + & + \\
6. Sweden & + & + & & + & + \\
7. Ukraine & + & & + & & \\
\hline
\end{tabular}

Source: compiled by the author and Kuprina (2011b).

The most profitable vertical-integrated agro-industrial companies in Ukraine that have proved profitability not only of production of their enterprises owned by the food industry, but also by the agrarian sector which is currently represented by the "Mironivsky Hliboproduct" Company (the trademark "Nasha Rya-Ba", "Easy!", "Friendship of Peoples", "Foie Gras", "Certified Angus", "Baschinsky", "Europroduct"), "Kernel Group" (TM "Shchedryi Dar", "Stozhar", "Chumak Home”, "Chumak Gold”, "Lyubonka"), Agroholding “Avangard” (Table 6) (Kuprina, 2011b). 
Table 6

The most profitable vertical-integrated structures of the agro-industrial complex of Ukraine

\begin{tabular}{|c|c|c|c|}
\hline Cluster & $\begin{array}{l}\text { Coverage of } \\
\text { the market of Ukraine }\end{array}$ & Scope of activity & $\begin{array}{l}\text { Territorial } \\
\text { location }\end{array}$ \\
\hline $\begin{array}{l}\text { 1. The company } \\
\text { "Mironovsky" } \\
\text { bread product, } \\
\text { (TM "Nasha Ryaba", } \\
\text { Easy!", } \\
\text { "Friendship } \\
\text { of Peoples", } \\
\text { "Foie Gras", } \\
\text { "Certified Angus", } \\
\text { "Bashchinsky", } \\
\text { "Europroduct") }\end{array}$ & $\begin{array}{l}\text { - about } 50 \% \\
\text { of the industrial } \\
\text { production } \\
\text { of chicken meat, } \\
\text { - 95\% brand } \\
\text { recognition among } \\
\text { consumers. }\end{array}$ & $\begin{array}{l}\text { 1. Poultry farming and } \\
\text { related production } \\
\text { (production of chilled } \\
\text { chicken, ready- } \\
\text {-made food products, } \\
\text { sunflower oil); } \\
\text { 2. Crop production } \\
\text { (growing corn, } \\
\text { sunflower, wheat, } \\
\text { rapeseed); } \\
\text { 3. Other agricultural } \\
\text { operations } \\
\text { (production of pork, } \\
\text { premium beef, } \\
\text { foie gras, sausage } \\
\text { products and } \\
\text { smoked meat, fruit, } \\
\text { production of animal } \\
\text { feed). }\end{array}$ & $\begin{array}{l}\text { Kiev region, } \\
\text { Cherkasy region, } \\
\text { Dnepropetrovsk } \\
\text { region, } \\
\text { Donetsk region, } \\
\text { Kherson region, } \\
\text { Ivano-Frankivsk region }\end{array}$ \\
\hline $\begin{array}{l}\text { 2. Kernel Group } \\
\text { Company } \\
\text { (TM "Generous } \\
\text { Gift", "Stozhar", } \\
\text { "Chumak House", } \\
\text { "Chumak Golden", } \\
\text { "Lyubonka") }\end{array}$ & $\begin{array}{l}\text { - } 35 \% \text { of the market of } \\
\text { bottled sunflower oil; } \\
\text { - grain trans-shipment } \\
\text { capacity - more } \\
\text { than } 20 \% \text { of the } \\
\text { total Ukrainian grain } \\
\text { exports } \\
\text { (one of the five } \\
\text { largest grain } \\
\text { exporters in Ukraine). }\end{array}$ & $\begin{array}{l}\text { 1. Production and } \\
\text { export of bottled } \\
\text { sunflower oil; } \\
\text { 2. Agricultural } \\
\text { production; } \\
\text { 3. Provision of services } \\
\text { for trans-shipment } \\
\text { of grain cargos and } \\
\text { oils in the ports of } \\
\text { Chornomorsk and } \\
\text { thecity of Nikolaev; } \\
\text { 3. Storage and export } \\
\text { of grain and oilseeds } \\
\text { in internal elevators. }\end{array}$ & $\begin{array}{l}\text { Vinnitsa region, } \\
\text { Dnepropetrovsk } \\
\text { region, } \\
\text { Donetsk region, } \\
\text { Zaporizhzhya region, } \\
\text { Kiev region, } \\
\text { Kirovograd region, } \\
\text { Lugansk region, } \\
\text { Lviv region, } \\
\text { Mykolaiv region, } \\
\text { Odessa region, } \\
\text { Poltava region, } \\
\text { Kharkov region, } \\
\text { Cherkasy region }\end{array}$ \\
\hline $\begin{array}{l}\text { 3. Agroholding } \\
\text { "Avangard" }\end{array}$ & $\begin{array}{l}-79 \% \text { of the } \\
\text { production } \\
\text { of eggs } \\
\text { and dry egg } \\
\text { products }\end{array}$ & $\begin{array}{l}\text { 1. Production of eggs } \\
\text { and egg products. } \\
\text { 2. Production of laying } \\
\text { hens and breeding } \\
\text { flocks at the end of } \\
\text { their cycle. }\end{array}$ & $\begin{array}{l}\text { Kiev region, } \\
\text { Khmelnitsky region, } \\
\text { Ivano-Frankivsk } \\
\text { region, } \\
\text { Chernivtsi region, } \\
\text { Mykolaiv region, } \\
\text { Kherson region, } \\
\text { Dnipropeptrovskaya } \\
\text { region, } \\
\text { Donetsk region, } \\
\text { Kirovograd region, } \\
\text { Kharkov region, } \\
\text { Lugansk region }\end{array}$ \\
\hline
\end{tabular}

Source: compiled by the author and Kuprina (2011b). 
The previous study showed that (Kuprina, 2011b), according to the analyses, the agrarian sector and food industry enterprises in Ukraine lead in the number of attracted investments and remain attractive for further investment, which is facilitated by stable production growth and high business profitability. For example, the Myronivsky Hliboprodukt Company is the most profitable meat producer in the world: its operating margin exceeds $30 \%$. The analysis of the activities of similar foreign companies shows that Cherkizovo, the largest Russian meat producer, works with an operating profit margin of around $15 \%$, while the leading American chicken producer Tyson Foods operates at 6\% (Mironova, 2017).

The results of the activity of these agro-industrial formations testify not only to their efficiency and competitiveness in the domestic, but also in the global market, as well as confirm that the creation of such structures of symbiosis of food industry enterprises and the agricultural sector will contribute to the formation of a sustainable and competitive national producer and may be the subject of the national economy, necessary for the formation of their own transnational structures.

\section{Summary and conclusions}

The conducted research allows to make the following conclusions:

1. The food industry in each country is a strategic industry that ensures its food security, social aspects are environmentally friendly, safe products and health of the population, its economic security, as it is stable even during periods of economic and political crises. Therefore, the state of the given industry and the efficiency of its operation require constant analysis and research.

2. The analysis of presence of food industry enterprises in Odessa region and their profitability showed that despite the fact that there is an increase in the number of food industry enterprises, including the increase due to the growth of small business, in some sub-sectors of the food industry the level of unprofitable enterprises reaches up to $38-40 \%$, and there is a tendency to decline in production and low profitability of products. The analysis of the state of the food industry in such a large and progressive region as Odessa region showed that there is a need to find the ways of adapting to the new conditions of functioning and overcoming crisis processes in the economy.

3. The conducted study made it possible to assert that the transformation of the activities of the food industry on the basis of the implementation of a system of measures (organizational, legal, financial, and economic and production-technical), allows to ensure and improve the competitiveness and efficiency of the business entity in accordance with changes in the external environment and the developed strategy of its development.

4. The direction of preserving the competitiveness and efficiency of the national producers in accordance with significant changes in the external environment is the formation of vertically integrated structures - holdings (strict transformation of activities), cluster formations and associations (moderate transformation of activities), implementation of activities based on other outsourcing approaches 
(soft transformation activities). Such structural changes in the organization of enterprises are becoming especially relevant in the conditions of openness of the internal market of Ukraine and trade liberalization.

5. Positive factors for the development of agro-industrial production are: changes in the global market conditions: global trend of growth of commodity markets; increase in the cost of food products; increase in the value of land resources; increase of the agricultural market of Ukraine and the need for quality products; introduction of more efficient business schemes. 


\section{References}

Ackoff, R.F., Magidson, D., Addison, H.J. (2007). Idealizovane proektuvannia: Yak zapobihty zavtrashnii kryzi sohodni. Stvorennia maibutnoho orhanizatsii [Ideal design: How to prevent tomorrow's crisis today. Creating a future organization]. Dnipropetrovsk: Balans Biznes Buks.

Alekseev, S.B. (2000). Obosnovanie neobhodimosti, osnovnyie printsipyi i soderzhanie podhoda adaptivnogo upravleniya na promyishlennom predpriyatii [Justification of the need, the basic principles and content of the approach of adaptive management in an industrial enterprise]. Ekonomicheskie Problemyi I Perspektivyi Stabilizatsii Ekonomiki Ukrainyi, No. 2, pp. 19-23.

Chizhenkova, E.V. (2005). Ekonomicheskiy mehanizm adaptatsii hozyaystvuyuschego sub'ekta $\mathrm{k}$ ryinochnoy srede [The economic mechanism of adaptation of the economic entity to the market environment]. Orel: OGIET.

Holovne upravlinnia statystyky v Odeskii oblasti [The Main Department of Statistics in the Odessa region]. Statystychnyi biuleten, Osnovni pokaznyky diialnosti malykh pidpryiemstv Odeskoi oblasti u 2017 rotsi [Statistical bulletin. The main indicators of activity of small enterprises of the Odessa region in 2017]. Odessa 2018, pp. 1-46.

Kapitanets, Y. (2007). Stratehichna adaptatsiia pidpryiemstva do zovnishnoho seredovyshcha [Strategic adaptation of the enterprise to the external environment]. Lviv Polytechnic National University Institutional Repository, pp. 257-261. Retrieved from: http://ena. 1p.edu.ua/bitstream/ntb/35562/1/38_257-261.pdf (access date: April 19, 2019).

Kozachenko, A.V., Ponomarev, V.P., Lyashenko, A.N. (2003). Ekonomicheskaya bezopasnost predpriyatiya: Suschnost i mehanizm obespecheniya [Economic security of an enterprise: The nature and mechanism of ensuring]. Kiev: Libra.

Kulikov, P. M. (2010). Teoretychni osnovy adaptatsii pidpryiemstva do minlyvosti otochuiuchoho sere-dovyshcha [Theoretical basis of adaptation of the enterprise to the variability of the environment]. Biznes-inform, 1(5), pp. 56-58.

Kuprina, N. M. (2011a). Imparitetnaya restrukturizatsiya promyishlennyih predpriyatiy kak instrument ih ekonomicheskoy bezopasnosti [Impartial restructuring of industrial enterprises as a tool for their economic security]. Rehionalnyi Zbirnyk Naukovykh Prats Z Ekonomiky. Donetskyi Ekonomiko-humanitaonyi Instytut MONMS Ukrainy, 3(36), pp. 226-229.

Kuprina, N.M. (2011b). Stratehichni napriamky rozvytku pidpryiemstv kharchovoi promyslovosti Ukrainy [Strategic directions of development of food industry enterprises of Ukraine]. In: A.I. Butenko, V.I. Liashenko, N.L. Shlafman (Authors) \& A.I. Butenko (Ed.), Stratehichni napriamky rozvytku pidpryiemnytskoho sektora Ukrainy (pp. 282-301). Odessa: Inter-print.

Kuprina, N.M. (2012). Transformatsiya deyatelnosti kak strukturnyiy komponent restrukturizatsii promyishlennyih predpriyatiy Ukrainyi [Transformation of activity as a structural component of the restructuring of industrial enterprises of Ukraine]. Sotsialno-ekonomicheskie Yavleniya I Protsessyi (11), pp. 143-147.

Kuprina, N.M. (2013). Persistentnost deyatelnosti v sisteme upravleniya restrukturizatsiey predpriyatiy pischevoy promyishlennosti [Persistence of activities in the management system of the restructuring of food industry enterprises]. Sotsialno-ekonomicheskie Yavleniya I Protsessyi (3), pp. 88-92.

Minko, I.S., Shamina, L.K. (2011). Adaptivnost i innovatsii v ekonomicheskih sistemah [Adaptability and innovation in economic systems]. Elektronnyiy Nauchnyiy Zhurnal $S P b G U N i P T$, "ekonomika i ekologicheskiy menedzhment". Retrieved from: http://economics.openmechanics.com/articles/295.pdf (access date: April 19, 2019). 
Mironova, I. (2017, March 11). Ukrainskaya zemlya plodit milliarderov [Ukrainian land breeds billionaires]. Retrieved from: http://www.news.mail.ru/inworld/ukraina/society /5482506/ (access date: April 19, 2019).

Porter, M. (2005). On Competition. Moscow: Vilyams.

Statystychnyi biuleten. Osnovni pokaznyky diialnosti malykh pidpryiemstv Odeskoi oblasti u 2017 rotsi [Statistical bulletin. The main indicators of activity of small enterprises of the Odessa region in 2017]. (2018). (pp. 1-46). Odesa: Holovne upravlinnia statystyky v Odeskii oblasti [The Main Department of Statistics in the Odessa region].

Znachenie terminov. Ekonomicheskiy slovar [Meaning of terms. Dictionary of Economics]. Retrieved from: http://vslovare.ru/slovo/jekonomicheskiij-slovar/ transformatzija/323348 (access date: April 19, 2019). 


\title{
WYDAJNOŚĆ PRZEMYSŁU SPOŻYWCZEGO NA UKRAINIE: ANALIZA I KIERUNKI OCHRONY KONKURENCYJNOŚCI
}

\begin{abstract}
Abstrakt
Przemyst spożywczy w każdym kraju jest branża strategiczna zapewniajaca bezpieczeństwo żywnościowe, promujaca zachowania społeczne przyjazne dla środowiska, gwarantujaca bezpieczeństwo produktów, zdrowie populacji i jej bezpieczeństwo ekonomiczne, działajaca nieprzerwanie nawet w czasie kryzysów gospodarczych i politycznych. W związku z powyższym stan branży oraz jej wydajność wymaga ciagtych analiz i badań.

$W$ niniejszej publikacji dokonano analizy funkcjonowania przemystu spożywczego na Ukrainie, ze szczególnym uwzględnieniem obwodu o istotnym znaczeniu dla jego rozwoju i przewag eksportowych - Odessy. Dokument podejmuje również kwestię zrównoważonego rozwoju i konkurencyjności przemystu spożywczego na Ukrainie.
\end{abstract}

Słowa kluczowe: gospodarka narodowa, przemysł spożywczy, restrukturyzacja, wydajność, konkurencyjność, transformacja działalności.

Accepted for print: 11.12.2019.

Unless stated otherwise all the materials on the website are available under 